\title{
Gambaran Penyesuaian Diri Warga Binaan Pemasyarakatan pada Sebuah Lapas Wanita di Indonesia
}

\author{
Zavelia Zuhriati Maghnina $^{1}$, Megah Andriany ${ }^{1 *}$ \\ ${ }^{1}$ Departemen Ilmu Keperawatan Fakultas Kedokteran Universitas Diponegoro, Semarang, Indonesia \\ megahandriany@gmail.com
}

\begin{abstract}
Introduction: Female inmates who newly admitted into prison has high stress level because she need to adapt with the environmental conditions, individuals, and rules that applicated in prison. In Indonesia there are no research about female inmates adjusment. The purpose of this study was to determine the description of female inmates adjustment in a female prison in Indonesia based the domains in the PAQ questionnaire and comparing the situation with outside of the prison.

Methods: This was a quantitative research with descriptive survey and cross-sectional design. The sampling technique used $n$ this research was total sampling with 46 respondents with criteria newly admitted into prison for 1-3 months. The sample criteria are able to write and read and willing to participate in the study. The data were collected using PAQ questionnaire.

Results: The results of this study show that dominant domain that worse in prisons compare with outside prisons was comfort and sleep problems. The most dominant problem that female inmates needs is sports, privacy, and sleep. The majority of female inmates have good friends while in prison, never feel prison as home, and all female inmate understand the rules in prison.

Conclusion: Nurses should provide nursing care to improve female inmates' self-adjustment in order to prevent mental health problems.
\end{abstract}

Keywords: Self Adjustment, Female Inmates, Prison.

\begin{abstract}
Abstrak
Pendahuluan: WBP (Warga Binaan Perempuan) yang baru masuk ke dalam Lapas mengalami stres yang tinggi karena dituntut untuk dapat menyesuaikan diri dengan kondisi lingkungan, individu, dan aturan yang berlaku di dalam Lapas. Di Indonesia belum pernah ada penelitian mengenai penyesuaian diri WBP. Tujuan penelitian ini adalah untuk mengetahui gambaran penyesuaian diri WBP pada sebuah Lapas wanita di Indonesia berdasarkan domain dalam kuesioner PAQ dan membandingkan dengan kondisi di luar Lapas.

Metode: Desain penelitian ini adalah kuantitatif dengan diskriptif survei dan pendekatan cross-sectional dengan total sampling sejumlah 46 responden dengan kriteria WBP yang baru masuk ke dalam Lapas selama 1-3 bulan. Data dikumpulkan dengan menggunakan kuesioner PAQ.

Hasil: Hasil penelitian menunjukan bahwa domain yang dominan lebih buruk di dalam lapas dibadingkan di luar Lapas adalah kenyamanan dan masalah tidur. Mayoritas WBP memiliki teman baik selama di Lapas, tidak pernah merasakan Lapas sebagai rumah, dan semua WBP paham peraturan yang ada di Lapas.

Kesimpulan: Perlu dilakukan asuhan keperawatan untuk meningkatkan penyesuaian diri WBP perempuan sebagai upaya pencegahan masalah kesehatan mental.
\end{abstract}

Kata Kunci: Penyesuaian Diri, WBP Perempuan, Lapas. 


\section{PENDAHULUAN}

Jumlah WBP di Indonesia setiap tahunnya mengalami peningkatan. Pada tahun 2013 sebanyak 5.315 orang, tahun 2014 sebanyak 5.629 orang, tahun 2015 sebanyak 6.292 orang, dan tahun 2016 sebanyak 7.587 orang (Direktorat Jendral Pemasyarakatan Kementerian Hukum dan Hak Asasi Manusia Republik Indonesia, 2016). Kondisi demikian mengakibatkan adanya ketidaksesuaian antara ketersediaan Lapas, jumlah WBP, dan jumlah staf (Putra, 2015). Hal ini menyebabkan rendahnya tingkat kenyamanan akibat terjadinya kepadatan, kesesakan, tidak adanya ruang pribadi, teritori, pembagian ruang bersama yang tidak proposional, kebutuhan makan yang tidak memadai, sanitasi yang buruk, kurangnya rekreasi, dan fasilitas olahraga (Anno, 2001; Segarahayu, 2011). Selain itu kurang maksimalnya pengamanan petugas Lapas, sehingga memungkinkan terjadinya perkelahian antar WBP, kurang perhatiannya kesehatan, dan akan berdampak pada psikologis WBP (Putra, 2015; Utami \& Pratiwi, 2011).

WBP lebih rentan mengalami masalah psikologis atau gangguan jiwa dibandingkan laki-laki seperti depresi, kecemasan, phobia, dan anti sosial (Ardilla \& Herdiana, 2013). Berdasarkan penelitian yang dilakukan oleh Shina diketahui bahwa terjadinya masalah kesehatan mental di Lapas terjadi tiga kali lebih tinggi dibandingkan di komunitas (Shina, 2010). Penelitian lain yang dilakukan oleh Picken juga menyatakan bahwa WBP yang baru masuk mengalami stress yang lebih tinggi dibandingkan dengan WBP yang sudah lama berada di Lapas (Picken, 2012). Hal ini karena WBP yang baru masuk dituntut untuk dapat menyesuaikan diri dengan kondisi lingkungan, individu, dan aturan-aturan yang berlaku di dalam Lapas (Amandari \& Sartika, 2015).

Kondisi yang demikian jika tidak diimbangi dengan koping diri yang baik mengakibatkan WBP akan merasa tertekan, kemudian mengembangkan perasaan dan cara berfikir yang negatif (Utami \& Pratiwi, 2011). Jika perasaan tersebut dibiarkan secara terus menerus akan menjadikan seseorang mengalami masalah dalam segi fisik, selain itu juga depresi, insomnia, harga diri rendah, mudah marah, hingga berisiko terjadinya bunuh diri (Anno, 2001; Asnita, Arneliwati, Jumaini, 2015; Utami,\& Pratiwi, 2011).

Berdasarkan hal tersebut, perawat pada populasi Lapas perlu memahami kondisi WBP secara menyeluruh terutama penyesuaian diri WBP perempuan untuk mencegah berkembangnya masalah kesehatan mental di Indonesia. Peran perawat di Lapas menjadi sangat penting dalam membantu WBP menyesuaikan diri di Lapas. Belum terdapat penelitian mengenai penyesuaian diri di Indonesia. Oleh karena itu peneliti tertarik untuk mengetahui bagaimana gambaran penyesuaian diri WBP pada sebuah Lapas di Indonesia. Hasil penelitian akan bermanfaat bagi perawat sebagai masukan dalam memberikan asuhan keperawatan bagi WBP untuk mencegah gangguan kesehatan fisik maupun mental.

\section{METODE}

Penelitian ini merupakan jenis penelitian non eksperimental dengan rancangan deskriptif survei. Populasi dalam penelitian ini adalah WBP yang baru masuk ke dalam suatu Lapas selama 1-3 bulan, yaitu sejumlah 46 WBP. Pengambilan sampel dalam penelitian ini menggunakan teknik total sampling, sehingga sampel yang digunakan adalah semua jumlah populasi. Kriteria sampel 
yang diterapkan adalah WBP yang mampu membaca tulis dan bersedia berpartisipasi dalam penelitian. Pengumpulan data dilakukan di sebuah Lapas wanita di Indonesia menggunakan prison adjustment questionnaire yang berisi 9 domain dan 7 item pertanyaan tambahan mengenai penyesuaian diri WBP. Prison adjustment questionnaire terdiri dari 28 item pertanyaan yang memiliki nilai validitas tiap item pertanyaan 0,449-0,865 (r tabel $=0,444$ ) yang berarti bahwa kuesioner valid untuk digunakan, dan nilai reliabilitas 0,746 . Analisis data menggunakan analisis univariat dengan penyajian data dalam bentuk tabel frekuensi dan presentasi. Penelitian ini dilakukan setelah mendapatkan ijin ethical clearance dari Komite Etik Penelitian Kesehatan Departemen Ilmu Keperawatan Fakultas Kedokteran Universitas Diponegoro.

\section{HASIL DAN PEMBAHASAN Perdebatan dengan Staf dan WBP Lain}

Banyaknya WBP yang tidak pernah berdebat di Lapas dikarenakan memiliki komunikasi interpersonal yang baik dengan petugas ataupun WBP lainnya. Perlakuan petugas yang ramah, dan WBP tidak seseram yang dibayangkan membuat hubungan antar individu menjadi baik (Ekasari \& Susanti, 2009). Kemampuan mengontrol emosi ketika baru masuk kedalam Lapas dapat dilakukan dengan mendekatkan diri kepada penciptanya (Ardilla, \& Herdiana, 2013).

Beberapa WBP yang pernah berdebat didalam Lapas dikarenakan memiliki perubahan emosi yang berbeda sejak masuk ke dalam Lapas (Ardilla, \& Herdiana, 2013). WBP mengaku bahwa memiliki batas kesabaran, emosi cenderung mudah tersulut, perasaan jengkel, dan ingin segala permasalahan cepat selesai membuat emosi semakin tidak terkonrol sejak berada di Lapas (Sari \& Nuqul, 2014).

\section{Keterlibatan dalam Perkelahian Fisik}

Masih adanya WBP yang berkelahi di Lapas, biasa dipicu masalah yang tidak serius tapi berakibat fatal. Beberapa faktor diantaranya seperti over kapasitas, perbandingan jumlah petugas dan penghuni yang tidak seimbang, pemahaman terhadap uraian tugas dan nilai-nilai HAM yang tidak merata, kesejahteraan petugas, keinginan WBP yang kuat untuk mendapat kebebasan dan kelonggaran, situasi dan kondisi yang monoton berlangsung lama, terjadi ketidak seimbangan antara isi dan blok penghuni, terjadinya perdebatan, dan emosi wanita yang tidak terkontrol (Rosifany, 2016; Sari \& Nuqul, 2014).

\section{Ketidaknyamanan WBP}

Lapas memiliki program perwalian yang bertujuan untuk meningkatkan hubungan WBP dengan staf agar WBP tetap merasa nyaman, terlindungi, tidak ada rasa takut, dan tidak nyaman di dalam Lapas. Perlakuan petugas Lapas yang ramah juga membuat hubungan antar individu menjadi baik (Ekasari \& Susanti, 2009).

Beberapa WBP yang merasa tidak nyaman berada disekitar WBP lain karena masih sering terjadi persaingan antara WBP sehingga menjadi stressor dan kekhawatiran tersendiri bagi WBP (Sunaryo, 2004). Situasi yang menegangkan dan membuat tidak nyaman akan membuat sesorang menjadi stress (Hidayati \& Sutini, 2017; Nasir \& Muhith, 2011).

\section{Masalah Tidur}

Salah satu masalah WBP selama di Lapas adalah sulit tidur. Sulit tidur terjadi lebih buruk ketika berada di dalam Lapas (Warren, Hurt, Loper, \& Chauhan, 2004). 
Tabel 1. Distribusi Frekuensi Karakteristik Responden pada Sebuah Lapas Wanita di Indonesia April-Juni 2017 (N=46)

\begin{tabular}{|c|c|c|c|}
\hline $\begin{array}{l}\text { Karakteristik } \\
\text { Rsponden }\end{array}$ & Kategori & $\begin{array}{l}\text { Frekuensi } \\
\text { (n) }\end{array}$ & $\begin{array}{l}\text { Persentase } \\
(\%)\end{array}$ \\
\hline \multirow[t]{7}{*}{ Usia } & 17-25 (Remaja Akhir) & 7 & 15,2 \\
\hline & 26-35 (Dewasa Awal) & 17 & 36,9 \\
\hline & 36-45 (Dewasa Akhir) & 13 & 28,3 \\
\hline & 46-55 (Lansia Awal) & 7 & 15,2 \\
\hline & 56-65 (Lansia Akhir) & 1 & 2,2 \\
\hline & $>65$ (Manula) & 1 & 2,2 \\
\hline & Total & 46 & 100 \\
\hline \multirow[t]{4}{*}{ Tingkat Pendidikan } & Pendidikan Rendah & 12 & 26,1 \\
\hline & Pendidikan Menengah & 23 & 50 \\
\hline & Pendidikan Tinggi & 11 & 23,9 \\
\hline & Total & 46 & 100 \\
\hline \multirow[t]{4}{*}{ Status Pernikahan } & Menikah & 18 & 39,1 \\
\hline & Belum Menikah & 8 & 17,4 \\
\hline & Janda & 20 & 43,5 \\
\hline & Total & 46 & 100 \\
\hline \multirow{4}{*}{$\begin{array}{l}\text { Lama waktu berada } \\
\text { di Lapas }\end{array}$} & 1 Bulan & 8 & 17,4 \\
\hline & 2 Bulan & 21 & 45,7 \\
\hline & 3 Bulan & 17 & 36,9 \\
\hline & Total & 46 & 100 \\
\hline \multirow[t]{12}{*}{ Tindak pidana } & Pencurian & 3 & 6,5 \\
\hline & Penggelapan & 9 & 19,5 \\
\hline & Penipuan & 6 & 13,0 \\
\hline & Narkotika & 15 & 32,6 \\
\hline & Perdagangan orang & 1 & 2,2 \\
\hline & Korupsi & 7 & 15,2 \\
\hline & Pencucian uang & 1 & 2,2 \\
\hline & Togel & 1 & 2,2 \\
\hline & Penadah & 1 & 2,2 \\
\hline & Pornografi & 1 & 2,2 \\
\hline & UUPA & 1 & 2,2 \\
\hline & Total & 46 & 100 \\
\hline \multirow[t]{3}{*}{ Status WBP } & Belum mendapatkan vonis & 27 & 58,7 \\
\hline & Sudah mendapatkan vonis & 19 & 41,3 \\
\hline & Total & 46 & 100 \\
\hline \multirow[t]{5}{*}{ Lama Hukuman } & $<1$ Tahun & 2 & 10,5 \\
\hline & 1-3 Tahun & 12 & 63,2 \\
\hline & 4-6 Tahun & 4 & 21 \\
\hline & 7-9 Tahun & 1 & 5,3 \\
\hline & Total & 19 & 100 \\
\hline
\end{tabular}


Tabel 2. Perbandingan Frekuensi Penyesuaian Diri WBP di Dalam dan di Luar Sebuah Lapas Wanita di Indonesia April-Juni 2017 (N=46)

\begin{tabular}{|c|c|c|c|c|}
\hline \multirow[t]{2}{*}{ Domain } & \multicolumn{4}{|c|}{ Frekuensi } \\
\hline & $\begin{array}{l}\text { Sering } \\
\text { Terjadi di } \\
\text { Dalam Lapas } \\
\text { n }(\%)\end{array}$ & $\begin{array}{l}\text { Sering } \\
\text { Terjadi di } \\
\text { Luar Lapas } \\
\text { n }(\%)\end{array}$ & $\begin{array}{l}\text { Sama Sering } \\
\text { Terjadi di Dalam } \\
\text { Maupun di Luar } \\
\text { Lapas } \\
\text { n }(\%)\end{array}$ & $\begin{array}{l}\text { Sangat Jarang } \\
\text { Terjadi di Dalam } \\
\text { Maupun di Luar } \\
\text { Lapas } \\
\text { n }(\%)\end{array}$ \\
\hline Perdebatan & $5 \quad(10,9)$ & $5(10,9)$ & $2(4,3)$ & $34(73,9)$ \\
\hline Perkelahian Fisik & $2(4,3)$ & $1 \quad(2,2)$ & $0 \quad(0)$ & $43(93,5)$ \\
\hline Kenyamanan dengan orang sekitar & $1 \quad(2,2)$ & $34(73,9)$ & $11(23,9)$ & - \\
\hline Masalah Tidur & $26(56,5)$ & $2(4,3)$ & $8 \quad(17,4)$ & $10(21,7)$ \\
\hline Marah & $15(32,6)$ & $5 \quad(10,9)$ & $5 \quad(10,9)$ & $21(45,6)$ \\
\hline Cedera Terluka & $4(8,7)$ & $1 \quad(2,2)$ & $0 \quad(0)$ & $41(89,1)$ \\
\hline Sakit & $12(26,1)$ & $0 \quad(0)$ & $2(4,3)$ & $32(69,6)$ \\
\hline Takut Diserang & $14(30,4)$ & $3(6,5)$ & $7(15,2)$ & $22(47,8)$ \\
\hline Merasa Dimanfaatkan & $6(13)$ & $9 \quad(19,6)$ & $5 \quad(10,9)$ & $26(56,5)$ \\
\hline
\end{tabular}

Tabel 2 menunjukkan bahwa domain yang paling dominan adalah lebih sering merasa nyaman dengan orang di sekitar ketika di luar Lapas $(73,9 \%)$, dan lebih sering memiliki masalah tidur ketika di dalam Lapas $(56,5 \%)$

Tabel 3. Distribusi Frekuensi Penyesuaian Diri WBP pada Sebuah Lapas Wanita di Indonesia April-Juni $2017(\mathrm{~N}=46)$

\begin{tabular}{|c|c|c|c|c|c|c|}
\hline \multirow[b]{2}{*}{ Domain } & \multirow[b]{2}{*}{ Sub Domain } & \multicolumn{5}{|c|}{ Frekuensi } \\
\hline & & $\begin{array}{c}\text { Sering } \\
\text { (Beberap } \\
\text { a kali } \\
\text { dalam } \\
\text { sehari) } \\
\text { n }(\%)\end{array}$ & $\begin{array}{c}\text { Setidak } \\
\text {-nya } \\
\text { Sekali } \\
\text { Dalam } \\
\text { Sehari } \\
\text { n }(\%)\end{array}$ & Kadang & Jarang & $\begin{array}{r}\text { Tidak } \\
\text { Pernah }\end{array}$ \\
\hline \multirow[t]{2}{*}{ Perdebatan } & Perdebatan dengan staf & $0(0)$ & $0(0)$ & $3(6,5)$ & $5(10,9)$ & $38(82,6)$ \\
\hline & $\begin{array}{l}\text { Perdebatan dengan WBP } \\
\text { lain }\end{array}$ & $0(0)$ & $2(4,3)$ & $6(13,1)$ & $10(21,7)$ & $28(60,9)$ \\
\hline Perkelahian Fisik & Perkelahian fisik & $0(0)$ & $2(4,3)$ & $1(2,2)$ & $3(6,5)$ & $40(87)$ \\
\hline \multirow{2}{*}{$\begin{array}{l}\text { Kenyamanan dengan } \\
\text { orang sekitar }\end{array}$} & Tidak nyaman dengan staf & $1(2,2)$ & $1(2,2)$ & $13(28,2)$ & $12(26,1)$ & $19(41,3)$ \\
\hline & $\begin{array}{l}\text { Tidak nyaman dengan WBP } \\
\text { lain }\end{array}$ & $8(17,4)$ & $4(8,7)$ & $17(37)$ & $13(28,2)$ & $4(8,7)$ \\
\hline Masalah Tidur & Masalah tidur & $16(34,8)$ & $7(15,2)$ & $3(6,5)$ & $9(19,6)$ & $11(23,9)$ \\
\hline Marah & Marah & $0(0)$ & $5(10,9)$ & $9(19,6)$ & $14(30,4)$ & $18(39,1)$ \\
\hline Cedera Terluka & Cedera terluka & $0(0)$ & $0(0)$ & $2(4,3)$ & $3(6,5)$ & $41(89,1)$ \\
\hline Sakit & Sakit & $5(10,9)$ & $1(2,2)$ & $10(21,7)$ & $18(39,1)$ & $12(26,1)$ \\
\hline Takut Diserang & Takut diserang & $2(4,3)$ & $1(2,2)$ & $8(17,4)$ & $12(26,1)$ & $23(50)$ \\
\hline Merasa Dimanfaatkan & Merasa dimanfaatkan & $5(10,9)$ & $1(2,2)$ & $7(15,2)$ & $7(15,2)$ & $26(56,5)$ \\
\hline
\end{tabular}

Tabel 3 menunjukkan bahwa sub domain yang paling dominan pernah terjadi di Lapas (sering, setidaknya sekali sehari, kadang, dan jarang) adalah tidak nyaman dengan WBP lain $(91,3 \%)$, masalah tidur $(76,1 \%)$, sakit $(26,1 \%)$. 
Tabel 4. Distribusi Frekuensi Kebutuhan pada Sebuah Lapas Wanita di Indonesia April-Juni 2017 $(\mathrm{N}=46)$

\begin{tabular}{|c|c|c|c|c|}
\hline & $\begin{array}{l}\text { Tidak Pernah } \\
\text { n }(\%)\end{array}$ & $\begin{array}{l}\text { Jarang } \\
\text { n }(\%)\end{array}$ & $\begin{array}{l}\text { Sering } \\
\mathrm{n}(\%)\end{array}$ & $\begin{array}{l}\text { Selalu } \\
\text { n }(\%)\end{array}$ \\
\hline Olahraga & $5(10,9)$ & $24(52,2)$ & $14(30,4)$ & $(6,5)$ \\
\hline Tidur & $6(13)$ & $17(37)$ & $14(30,4)$ & $(19,6)$ \\
\hline Makan & $1(2,2)$ & $2(4,3)$ & $21(45,7)$ & $22 \quad(47,8)$ \\
\hline Aktivitas & $2(4,3)$ & $8(17,4)$ & $19(41,3)$ & $17 \quad(37)$ \\
\hline Privasi & $8(17,4)$ & $16(34,8)$ & $7(15,2)$ & $15 \quad 32,6)$ \\
\hline
\end{tabular}

Tabel 4 menunjukkan bahwa masalah kebutuhan yang mendominasi adalah olahraga $(10,9 \%$ tidak pernah dan $52,2 \%$ jarang merasa cukup olahraga), privasi (17,4\% tidak pernah, dan $34,8 \%$ jarang mendapat cukup privasi), dan tidur (13\% tidak pernah, dan $37 \%$ jarang merasa cukup tidur).

Tabel 5. Distribusi Frekuensi Kepemilikan Teman Baik pada Sebuah Lapas Wanita di Indonesia April-Juni 2017 (N=46)

\begin{tabular}{ccc}
\hline Tidak Ada n (\%) & Beberapa n (\%) & \multicolumn{2}{c}{ Banyak n (\%) } \\
\hline $5(10,9)$ & $24(52,2)$ & $17 \quad(36,9)$
\end{tabular}

Tabel 5 menunjukkan bahwa mayoritas WBP memiliki teman baik ketika berada di dalam Lapas (52,2\% beberapa, dan $36,9 \%$ banyak)

Tabel 6. Distribusi Frekuensi Perasaan Bahwa Lapas adalah Rumah Bagi WBP pada Sebuah Lapas Wanita di Indonesia April-Juni 2017 (N=46)

\begin{tabular}{|c|c|c|c|}
\hline Tidak Pernah n (\%) & Jarang n (\%) & Sering n (\%) & Selalu n (\%) \\
\hline $37(80,5)$ & $6(13)$ & $(2,2)$ & $2(4,3)$ \\
\hline
\end{tabular}

Tabel 6 menunjukkan bahwa sebagian besar WBP tidak pernah merasakan Lapas sebagai rumahnya (80,5\% tidak pernah, dan $13 \%$ jarang merasa).

Tabel 7. Distribusi Frekuensi Pemahaman WBP Terhadap Peraturan yang Berlaku pada Sebuah Lapas Wanita di Indonesia April-Juni 2017 (N=46)

\begin{tabular}{cccc}
\hline Tidak Pernah n (\%) & Jarang n (\%) & Sering n (\%) & Selalu n (\%) \\
\hline $0(0)$ & $0(0)$ & $12(26,1)$ & $34(73,9)$
\end{tabular}

Tabel 7 menunjukkan bahwa mayoritas WBP paham dengan peraturan di Lapas (73,9\% selalu, dan $26,1 \%$ sering memahami).

Sulit tidur atau insomnia merupakan salah satu respon fisiologis yang timbul karena stress psikososial ketika sesorang merasa memiliki beban yang melebihi kemampuannya (Anggraini, 2014; Segarahayu, 2011). Oleh karena itu WBP harus mampu menyesuaikan dirinya di kehidupannya yang baru (Anggraini, 2014). Faktor-faktor yang mempengaruhi kualitas dan kuantitas tidur adalah seperti penyakit fisik, efek samping obat-obatan, gaya hidup, pola tidur, stress emosional, lingkungan, latihan fisik dan kelelahan, asupan makanan, kalori, dan ruangan 
tempat WBP tidur (Patrimarati \& Ramadhani, 2015; Potter, \& Perry, 2005).

\section{Perasaan Marah}

WBP mengalami perubahan emosi yang berbeda sejak masuk ke Lapas, salah satunya adalah menjadi lebih temperamen atau mudah emosi (Ardilla, \& Herdiana, 2013). Mudah marah merupakan salah satu aspek emosinal gejala stress yang merupakan respon yang dilakukan oleh sesorang ketika menerima keadaan yang tidak menyenangkan dan membuat frustasi (Nasir \& Muhith, 2011; Segarahayu, 2011). Adanya gangguan emosi yang dialami WBP dapat menjadi hambatan bagi WBP untuk menerima dirinya (Ardilla, \& Herdiana, 2013).

\section{Kejadian Cedera atau Terluka}

WBP yang mengalami cedera atau terluka bisa disebabkan beberapa kejadian. Wanita lebih sering cedera akibat terjatuh dan terkena benda tajam atau tumpul. Jenis cedera akibat jatuh yang dialami seperti lecet, luka akibat benturan atau memar, luka terbuka, dan terkilir (Riyadina, 2009). Cedera yang mengakibatkan kecacatan bagi seseorang dapat menyebabkan stres (Hidayati \& Sutini, 2017).

\section{Pengalaman Sakit}

Lebih banyak WBP yang mengalami masalah kesehatan fisik ketika di Lapas (Wright, 1991). Suatu beban atau sesuatu yang melebihi kemampuan seseorang dapat membahayakan bagi kesehatannya, sehingga akan memberikan dampak pada fisiologis, emosional, kognitif, dan perilaku. Sakit merupakan salah satu dampak fisiologis dari terjadinya gejala stres (Segarahayu, 2011). Pemberian pelayanan kesehatan pada WBP mengalami beberapa kendala seperti kelebihan penghuni, petugas Lapas yang kurang, dan dana yang minim.

\section{Perasaan Takut Diserang}

Adanya WBP yang pernah merasa takut diserang karena adanya ancaman. Ancaman ini bisa berbentuk situasi menegangkan yang dihadapi oleh WBP, sehingga menjadi tidak nyaman dan stress (Hidayati \& Sutini, 2017; Nasir \& Muhith, 2011). Akibatnya, dapat terjadinya harga diri yang rendah (Kusuma, 2015). WBP yang menilai keadaannya sebagai beban atau sesuatu yang melebihi kemampuannya akan membahayakan bagi kesehatan dirinya (Segarahayu, 2011). Sedangkan, WBP yang tidak merasa takut diserang karena adanya hubungan yang baik antara WBP dengan staf dan WBP lain.

\section{Perasaan Dimanfaatkan oleh Staf dan WBP Lain}

Banyaknya WBP yang tidak pernah merasa dimanfaatkan oleh orang lain ini dikarenakan WBP diperlakukan layaknya masyarakat pada umumnya, diberi kebebasan berpikir, menyampaikan pendapat, menganut, beribadah sesuai kepercayaan, dan berkegiatan sosial dengan ruang gerak fasilitas dan gaya hidup yang terbatas, sehingga WBP mendapatkan banyak pengetahuan, pengalaman, dan ketrampilan baru (Devi, 2015).

\section{Kebutuhan Olahraga}

Beberapa WBP merasa tidak pernah cukup olahraga karena ruang lingkup untuk berolahraga sangat sedikit bahkan nyaris tanpa terprogram dengan baik, sehingga aktifitas gerak dan olahraga sangat kurang (Sukendro, Indrayana, \& Rasyono, 2016). Akibatnya, secara fisiologis WBP yang kurang berolahraga membuat kesehatan tubuhnya menjadi terganggu, dan terjadi penurunan metabolisme energi yang akan mempengaruhi fungsi organ tubuh (Purnamasari et al., 2013). Beberapa olahraga yang dapat dilakukan di dalam 
Lapas dan dapat dilakukan oleh siapa saja seperti permainan bola voli, futsal dan aerobic secara signifikan dapat menjaga kebugaran jasmani (Sukendro, Indrayana, \& Rasyono, 2016).

\section{Kebutuhan Makan}

Lapas memiliki tanggung jawab untuk memenuhi kebutuhan makan WBP. Selama berada di Lapas WBP mendapatkan makan tiga kali dalam sehari. Tapi menu yang disediakan tidak bervariasi, lebih sering mendapatkan tempe, tahu, dan ikan asin. Hal ini dikarenakan anggaran untuk makan WBP setiap harinya sangat minim (Patrimarati \& Ramadhani, 2015). WBP diperbolehkan mendapat lauk dari keluarga jika tidak ingin makan makanan yang tersedia sehingga kebutuhan makan WBP tetap terpenuhi.

\section{Kebutuhan Aktivitas}

Adanya WBP yang merasa belum cukup aktivitas ini dikarenakan kurangnya minat atau kemauan untuk mengembangkan dirinya melalui kegiatan pembinaan yang dilaksanakan di Lapas (Rosifany, 2016). Padahal kurangnya aktivitas dapat mengakibatkan masalah kesehatan fisik (Wright, 1991).

Sedangkan, WBP yang merasa cukup aktivitas ini dikarenakan Lapas memiliki banyak kegiatan seperti kegiatan keagamaan, pelatihan ketrampilan, olah raga seperti sepak bola, volly, senam, dan kegiatan penyaluran hobi seperti band, dan organ tunggal (Ekasari \& Susanti, 2009). Kegiatan ini dapat membuat WBP memiliki kemampuan, minat, potensi yang dapat digunakan dan dikembangkan pada saat sudah keluar dari Lapas, dan tidak akan merasa bosan karena sibuk dengan pekerjaan atau pelatihan yang disediakan oleh Lapas (Banjarnahor, 2017).

\section{Kebutuhan Privasi}

Privasi merupakan suatu kemampuan untuk mengontrol interaksi, memperoleh pilihan, dan mencapai interaksi seperti yang diinginkan (Prabowo, 1998). Banyaknya WBP yang merasa cukup mendapatkan privasi dikarenakan privasi merupakan salah satu hak WBP ketika berada di Lapas (Fatony et al., 2016).

Beberapa faktor yang mempengaruhi privasi, yaitu faktor personal yang berasal dari latar belakang seseorang, situasional yang berasal dari situasi fisik sekitar, budaya karena setiap budaya masingmasing memiliki standar privasi dan cara memperoleh privasi, dan kepadatan yaitu banyaknya orang dalam suatu tempat mempengaruhi jarak sosial.

\section{Kepemilikan Teman Baik}

Memiliki hubungan baik dengan WBP lain atau staf merupakan salah satu faktor tercapainya kebahagiaan yang berasal dari eksternal. Orang yang berbahagia akan memiliki lebih banyak teman biasa, teman dekat, lebih mungkin untuk menikah, dan lebih terlibat dalam kegiatan berkelompok. Menjalin hubungan yang baik dilakukan WBP dengan cara sering berkumpul, memberikan waktunya untuk berinteraksi, dan mendekatkan diri dengan Tuhan (Lewi \& Sudarji, 2017). Perlakuan petugas yang ramah dan WBP tidak seseram yang dibayangkan membuat hubungan antar individu menjadi baik (Ekasari \& Susanti, 2009).

\section{Perasaan bahwa Lapas adalah Rumah}

Banyaknya WBP yang tidak pernah merasa bahwa Lapas adalah rumahnya dikarenakan setiap hari WBP dihadapkan dengan tembok dan jeruji besi di dalam tempat yang dibatasi ruang lingkup, komunikasi, aktivitas, dan segala sesuatu yang terbatas dalam jangka waktu tertentu tentu akan menjadikan kebosanan dan 
kejenuhan (Purnamasari et al., 2013; Sukendro, Indrayana, \& Rasyono, 2016). Kondisi tersebut dapat membuat WBP merasa tertekan, mengembangkan perasaan dan cara berpikir yang negatif selama berada di Lapas.

\section{Pemahaman terhadap Peraturan- Peraturan di dalam Lapas}

WBP yang melanggar peraturan akan mendapatkan hukuman atau sanksi dari pihak Lapas. Hukuman yang akan diberikan dilihat dari jenis dan tingkat kejahatan yang dilakukan yaitu dari mulai teguran, pemberian tugas tertentu penyitaan barang, pengasingan, dilaporkan kepada pihak berwajib untuk diproses lebih lanjut, dan dilakukan pencabutan hak-hak seperti tidak bisa dibesuk oleh siapa pun baik keluarga maupun teman dalam jangka tertentu, tidak atau dicabut remisi, tidak mendapatkan asimilasi, pembebasan bersyarat, cuti menjelang bebas, dan cuti bersyarat (Sumarauw, 2013).

Perawat dapat melakukan implikasi keperawatan dengan dominan masalah yang terjadi didalam Lapas yaitu melakukan edukasi kepada WBP terhadap pencegahan dan penanganan penyakit, serta kepada keluarga tentang pentingnya kunjungan terhadap psikologis WBP. Perawat mampu menjadi konselor untuk masalah psikologis WBP dan melindungi hak WBP seperti memenuhi kebutuhannya dengan berkolaborasi dengan tenaga kesehatan lain dan pihak Lapas sehingga WBP dapat merasakan Lapas sebagai rumahnya.

\section{KESIMPULAN DAN SARAN}

Kesimpulan dari penelitian ini yaitu domain kenyamanan dan masalah tidur merupakan suatu domain yang paling dominan terjadi di dalam Lapas jika dibandingkan dengan di luar Lapas. Kemudian ketika berada didalam Lapas, frekuensi terjadinya masalah tidur, tidak nyaman dengan WBP lain, dan kejadian sakit merupakan sub domain yang paling dominan. Sedangkan masalah kebutuhan WBP yang paling dominan ketika berada di dalam Lapas yaitu olahraga, privasi dan kebutuhan tidur. Ketika berada di Lapas, mayoritas WBP memiliki teman baik, tidak pernah merasakan Lapas sebagai rumahnya, dan semua WBP selalu dan sering memahami peraturan yang ada di Lapas. Hasil penelitian ini menyarankan perlunya asuhan keperawatan yang membantu proses penyesuaian WBP perempuan dalam lingkungan Lapas sehingga masalah-masalah kesehatan baik fisik maupun mental dapat dicegah secara dini.

\section{UCAPAN TERIMA KASIH}

Peneliti mengucapkan terimakasih kepada responden, tempat penelitian, serta rekan-rekan dan semua pihak yang telah membantu proses penelitian ini.

\section{DAFTAR PUSTAKA}

Amandari, S. L. \& Sartika, D. (2015). Hubungan character strength dengan penyesuaian diri yang efektif pada narapidana di Lapas Sukamiskin Kelas IIA Bandung. Prosiding Psikologi, 1(2), 519-525.

Anggraini, P. (2014). Hubungan antara tingkat stres dengan kejadian insomnia pada WBP di Lembaga Pemasyarakatan Kelas IIA Kabupaten Jember. Universitas Jember.

Anno, B. J. (2001). Correctional health care: Guidelines for the management of an adeqate delivery system. Washington: National Commissions on Correctional Health Care. 
Ardilla, F \& Herdiana, I. (2013). Penerimaan diri pada wanita WBP. Jurnal Psikologi Kepribadian dan Sosial, 2(1).

Asnita, Arneliwati, Jumaini. (2015). Hubungan tingkat stress dengan harga diri remaja di lembaga pemasyarakatan. Jurnal Online Mahasiswa, 2(2), 1231-40.

Banjarnahor. R. (2017) Implementasi hakhak narapidana menurut Undang Undang Lembaga Pemasyarakatan (UU No.12 Tahun 1995) (Studi Kasus Lembaga Pemasyarakatan Tondano). Lex Administratum, 5(2), 29-36.

Devi, R. R. P. (2015). Resiliensi narapidana dewasa di Lembaga Pemasyarakatan Klas IIA Sragen. Universitas Muhammadiyah Surakarta.

Direktorat Jenderal Pemasyarakatan Kementerian Hukum dan Hak Asasi Manusia Republik Indonesia. (2016). Sistem database pemasyarakatan: Data terakhir jumlah penghuni perkanwil.

Ekasari, A \& Susanti, N. (2009). Hubungan antara optimisme dan penyesuaian diri dengan stress pada narapidana kasus NAPZA di Lapas Kelas IIA Bulak Kapal Bekasi. SOUL, 2(2), 1-32.

Fatony, A., Aditantyo, A., Arvani, C. N., Valerian, D., Widigda, \& Paladina, K. M. (2016). Efektivitas pelaksanaan hak WBP perempuan dalam mewujudkan tujuan pemasyarakatan: Studi kasus Rumah Tahanan Klas II A Jakarta Timur. Jurnal Hukum \& Pembangunan, 45(3), 377-407. doi:10.21143/jhp.vol45.no.3.54
Hidayati, N. O., \& Sutini, T. (2017). Gambaran harga diri WBP perempuan di Lembaga Pemasyarakatan $X$ Bandung. Jurnal Keperawatan BSI, 5(1), 1-7.

Kusuma, Y. L. H. (2015). Pengaruh bimbingan metode diskusi terhadap perubahan harga diri narapidana di Lapas Kelas IIB Kota Mojokerto. Hospital Majapahit, 7(2), 54-66.

Lewi, N. \& Sudarji, S. (2017). Faktorfaktor pendukung kebahagiaan pada empat narapidana wanita di Lapas Wanita Kelas II A Tangerang. Psibernetika, 8(2)

Nasir, A., \& Muhith, A. (2011). Dasardasar keperawatan jiwa pengantar dan teori. Jakarta: Penerbit Salemba Medika.

Patrimarati, U., \& Ramadhani, D. (2015). Hubungan antara tingkat stres dengan kejadian insomnia pada WBP di Lembaga Pemasyarakatan Kelas IIA Kabupaten Jember.

Picken J. (2012). The coping strategies, adjustment and well being of male inmates in the prison environment. Internet Journal of Criminology.1-29

Potter, P. A., \& Perry, A. G. (2005). Buku ajar fundamental keperawatan: Konsep, proses, dan praktik. Ed 4. Jakarta: EGC.

Prabowo, H. (1998). Pengantar psikologi lingkungan. Jakarta: Gunadarma.

Purnamasari, M. B., Made, N., Sukawana, Wayan. I, Suarnatha. Ketut. (2013). Pengaruh senam aerobik low impact terhadap penurunan tingkat depresi pada narapidana wanita di Lembaga 
Pemasyarakatan Denpasar. Diperoleh dari https://www.ejurnal.com/2014/10/pengaruh-senamaerobik-low-impact.html

Putra, I. P. S. W. S. (2015). Dampak kelebihan kapasitas lembaga pemasyarakatan sebagai faktor kriminogenik terhadap pengulangan tindak pidana oleh WBP. Malang, Universitas Brawijaya.

Riyadina, W. (2009). Profil cedera akibat jatuh kecelakaan lalu lintas dan terluka benda tajam/tumpul pada masyarakat Indonesia. Vektora, 1(1), 1-11.

Rosifany, O. (2016). Pembinaan WBP Pemasyarakatan Wanita Di Lembaga Pemasyarakatan Klas II A Samarinda. Dedikasi, 34(1).

Sari, I. N. \& Nuqul, F. L (2014). Criminal thinking pada narapidana wanita. Prosiding Temu Ilmiyah Asosiasi Psikologi Forensik "Peran Psikologi Forensik dalam Penerapan Restorative Justice dan Viktimologi", Malang, 1-14.

Segarahayu, R. (2011) Pengaruh manajemen stress terhadap penurunan tingkat pada narapidana di LPW Malang. Universitas Negeri Malang.

Shina, S. (2010). Adjustment and mental health problem in prisoners, Industrial Psychiatri Journal, 19(2):101-4.

Sukendro, Indrayana, B., \& Rasyono. (2016). Pemberian pelatihan olahraga pada penghuni Lapas Wanita Provinsi Jambi. Jurnal Pengabdian pada Masyarakat, 31(2), 54-62.

Sumarauw, Y. (2013). Narapidana perempuan dalam penjara (suatu kajian antropologi gender). HOLISTIK, VI(11B), 1-17.

Sunaryo. (2004). Psikologi untuk keperawatan. Jakarta: EGC.

Utami, R \& Pratiwi, M. M. S. (2011). Tingkat Depresi Pada WBP (Studi Deskriptif WBP LAPAS Kelas IIA Semarang). Jurnal Asvattha, 1(4), 40 7.

Warren, J. I., Hurt, S., Loper, A. B., \& Chauhan, P. (2004). Exploring prison adjusment among female inmates. Criminal Justice Behavior, 31(5), 624645. doi: 10.1177/0093854804267096

Wright, K. N. (1991). A study of individual, environmental, and interactive effects in explaining adjustment to prison. Justice Quarterly, 8(2), 217-242. doi: $10.1080 / 07418829100091011$ 